\title{
The dark-side of coopetition: It's not what you say, but the way that you do it
}

\begin{abstract}
This study, underpinned by the Resource-Based View, contributes to our understanding of the dark-side of marketing regarding unwanted and undesirable behaviour that may be detrimental to businesses. It involves regional coopetition (simultaneous collaboration and competition) within New Zealand's wine sector. Owner-managers of 25 vineyards were interviewed to understand their views towards the potential paradox of coopetition together with another 13 managers that worked at the cellar door (38 interviews in total); also, observations of employees at 13 cellar doors to establish whether what owner-managers claimed was implemented as a 'strategy as practice' to customers. In contributing to knowledge, the study finds that although owner-managers of under-resourced firms may advocate the benefits of coopetition to enhance performance, observations indicate that certain front-line employees' practices were inconsistent with the views of ownermanagers. The findings have implications for the way owner-managers recruit, train and incentivise employees to facilitate performance-enhancing service marketing strategies.
\end{abstract}

Keywords: Coopetition; Dark-Side; New Zealand; Resource Based View

\section{Introduction}

"There may be some inconsistencies between what managers say, and what they do" (Kraft, 1991, p. 485).

The need to enter collaborative inter-firm relationships is a fundamental value-adding strategic marketing decision for particular management teams in under-resourced firms regarding enhancing their resource base (Felzensztein et al., 2018; Granata et al., 2018;

Ryan et al., 2019). This current study builds on a platform of cross-disciplinary work involving: both the entrepreneurial strategy-marketing interface (Crick, 2018a) and economic geography-marketing interface (Nicholson et al., 2017). It focuses on the notion of 'coopetition' as one form of inter-firm collaboration, defined by Bengtsson \& Kock (2014, p. 180) as "a paradoxical relationship between two or more actors, regardless of whether they are in horizontal or vertical relationships, simultaneously involved in cooperative and competitive interactions". In line with the previously mentioned crossdisciplinary literature, it has typically been conceptualised as a managerial mind-set or set 
of firm-level behaviours associated with the sharing of resources and capabilities between rival businesses to enhance their performance (Bengtsson \& Kock, 2000; Ritala \& Hurmelinna-Laukkanen, 2009; Rusko, 2011; Dahl, 2014; Park et al., 2014; Bengtsson \& Raza-Ullah, 2016; Gnyawali \& Charleton, 2018; Crick \& Crick, 2019). From a resourcebased view (RBV) perspective, inference is drawn from existing studies that in the event management teams in under-resourced firms collaborate with their competitors, they have access to more resources and capabilities that may enhance their performance; namely, in comparison to businesses competing on an individualistic-level (Combs \& Ketchen Jnr, 1999; Gnyawali \& Park, 2009; Ritala, 2012; Crick, 2019a).

Consequently, given the link between firms' resources and enhanced performance resulting from management teams engaging in coopetition, it is not surprising that research interest continues into aspects of inter-firm collaboration (Arslan, 2018; Bouncken et al., 2018; Felzensztein et al., 2018; Hannah \& Eisenhardt, 2018; Mathias et al., 2018). Nevertheless, prior research notes the need to manage potential tensions that can arise among firms due to the potential paradoxical nature of a coopetition strategy; that is, to avoid negative implications for performance (Fernandez et al., 2014; Raza-Ullah, et al., 2014; Tidstrom, 2014; Bengtsson et al., 2016). However, the extent to which managers implement a coopetition mind-set within their respective business to overcome potential tensions remains relatively under-researched. This consideration is important in a service context as there is a sometimes a lack of research with a strong managerialapplied focus (Klaus \& Edvardsson, 2014); additionally, there are doubts about the role of the marketing function within organisations (Verhoef \& Leeflang, 2009).

Therefore, to contribute to the existing literature, this current study builds on the previously mentioned notion of tensions in coopetition (Fernandez et al., 2014; Raza-Ullah et al., 
2014; Tidstrom, 2014; Bengtsson et al., 2016). Specifically, the research objective is to further the current understanding of the dark-side of strategic marketing practices that can negatively affect firms' performance; that is, with a focus on the implementation of coopetition activities impacting on the service offered by front line employees to customers. The applied managerial focus of this mixed methods study is relevant. A potential exists for differences regarding what management teams may claim in interviews in respect of the link between resources and performance-enhancing strategies (under the RBV) and what is observable in practice regarding employees' service interaction with customers. This is because of potential 'dark-side' practices associated with part of respective firms' marketing function involving unwanted and undesirable behaviour that in certain cases may be detrimental to businesses' activities (Harris \& Daunt, 2011; Daunt \& Harris, 2014; Daunt \& Greer, 2015; Greer, 2015).

In addressing the research objective, this current investigation draws on an 'adapted' strategy as practice approach (as per Whittington, 1996; 2006; Jarzabkowski et al., 2007; Burgelman et al., 2018; Jarzabkowski \& Bednarek, 2018). It contributes to our understanding concerning the extent to which employees at the interface with customers enhance the sales performance of their own firm rather than collaborating with competitors for mutual performance benefits, namely, as might be expected under the RBV in coopetition relationships. This study is timely as it builds upon ongoing research highlighting the importance of inter-firm relationships in regional clusters (Dana \& Winstone, 2008; Felzensztein \& Deans, 2013; Felzensztein et al., 2014; 2018; 2019; Geldes et al., 2015; Crick, 2018a; 2018b; Granata et al., 2018). This earlier research has investigated contrasting product-market strategies such as core product (such as wine) sales domestically and overseas in addition to domestic tourism activities. A $2 \times 2$ matrix is utilised in this current investigation to differentiate firms employing narrow and augmented 
product portfolios together with low and high levels of coopetition. The findings indicate that certain front-line service practices at the employee/customer interface were inconsistent with the views of owner-managers adding to our understanding of aspects of the dark-side of strategic marketing.

This study is important since some dark-side practices have implications for the way owner-managers recruit, train and incentivise employees that interact with customers. In fact, observations within this current investigation suggest certain employees' service behaviour was subtle, but still unhelpful, in potentially bringing back repeat custom or even increasing tourism to regional clusters that may affect sales for firms engaged in coopetition. In other words, the resource-enhancing nature of coopetition within clusters, consistent with the RBV, may not be fully implemented as a strategy as practice. Ideally, organisational practices are consistent throughout firms and what managers say, becomes implemented at the front line between employees and customers. Specifically, the study's research question follows: to what extent are practices at the customer interface consistent with decision-makers' coopetition strategies?

\section{Literature Review}

Resource Based Theory and the Link to Coopetition

Under the RBV that provides the underpinning theoretical lens of this current investigation, firms' resources (tangible assets like equipment and cash) and capabilities (intangible assets such as knowledge) are utilised to facilitate management teams enhancing their particular firm's performance (Barney, 1991; 2001; 2014). An assumption exists that firms with a greater volume of resources and capabilities often have more scope to obtain enhanced levels of company performance in comparison to firms with fewer resources 
and capabilities. The RBV is an appropriate lens to underpin this current study, given the notion of collaborating firms accessing resources and capabilities from competitors in performance-enhancing relationships (Combs \& Ketchen Jr., 1999). In fact, recently, Barney (2018) notes the importance of potential stakeholders that may enhance resourceperformance relationships. Consistent with the nature of regional clusters in this current investigation, research has extended the RBV to include the competitive business environment (Priem \& Butler, 2001). Additionally, the Relational View extends the RBV that takes into account the quality of network relationships (Dyer \& Singh, 1998; Dyer et al., 2018). In respect of the wider service marketing literature, Grönroos (1990) highlights the importance of a relational approach to service contexts; likewise, recognition of the broader issue of 'trust' in relationships exists (Sekhon et al., 2014).

Together, these resource-enhancing relational issues are relevant to varying extents in certain regional clusters given the different product-market strategies employed by ownermanagers, together with other contingencies or moderating factors like the relative competitive intensity (Felzensztein et al., 2014; 2018; 2019; Bengtsson et al., 2016; Yu \& Lindsay, 2016; Crick, 2018a; 2019b; Granata et al., 2018). Although further consideration follows later in this paper in the context of the New Zealand (NZ) wine industry, for now, as Crick \& Crick (2015) point out, particular firms in wine clusters serve core wine products domestically and overseas as well as wine tourism in the domestic market. This current study therefore notes ways that the relational aspects of coopetition under the RBV helps mitigate the role of the competitive environment addressed by firms, but only up to a point. After a certain point, 'dark-side' practices are evident among particular types of firms based on their product-market strategies. However, in line with the service focus of this journal's special issue, this investigation concentrates on domestic tourism as opposed to overseas sales. 


\section{Coopetition Paradox and the Specific Wine Sector Context}

Lado et al. (2006) highlight the utility of adopting a paradox lens to understand divergent thinking around the complex nature of a juxtaposed phenomenon. In transcending the coopetition paradox, the importance of studies regarding this topic both for researchers in the marketing discipline and practitioners can aptly be noted from Raza-Ullah et al.'s (2014, p189) observation that: "despite increased acceptance of coopetition in scientific circles, we know little concerning the nature and materialization of this paradox". The under-researched potential paradox in the sector context under investigation is worth consideration, since as previously alluded, certain vineyards compete via different product-market strategies (Crick \& Crick, 2015; Felzensztein et al., 2014; 2019).

Competitive aspects of the global wine sector exist in prior studies (Taplin, 2006; 2012; Voronov et al., 2013; Yu \& Lindsay, 2016). Within this, the NZ wine sector has faced a high degree of competition for some time that has affected particular brands' performance (Beverland, 2004; Crick \& Crick, 2015). Recent data suggests NZ contributes about 2 percent of worldwide sales (New Zealand Winegrowers, 2018) and is a new rather than old world wine producing country such as France and Italy; an issue that can affect perceptions towards the country of origin (Thorpe, 2009; Bruwer \& Beller, 2012). Industry data suggests that a number of smaller NZ wine producers have experienced problems with profitability. Consequently, wine tourism is important, providing an incentive for firms in clusters (similar to counterparts in certain other countries, Felzensztein et al., 2014; Crick, 2018a; Granata et al., 2018) to collaborate to boost wine sales and related tourist activities. 
A consultancy study (Deloitte, 2017) suggests that "wine tourists spend an average of $\$ 4500$ per visit to New Zealand” (p.3). Moreover, (p.6) income statements suggest an average profit/loss before tax as follows: those with revenues of more than $\$ 20$ million produced pre-tax profits of $20.6 \%$; $\$ 10-20$ million $16.3 \%$; $\$ 5-10$ million $9.9 \%$; $\$ 1.5-5$ million $5.3 \%$; and $\$ 0-1.5$ million losses of $3.1 \%$. This secondary data based on averages suggests a relationship exists between enhanced financial performance and economies of scale. Nevertheless, past research (Crick \& Crick, 2015) suggests that the objectives of owner-managers of boutique vineyards with lower revenues differ. Certain ownermanagers struggle to implement growth strategies in comparison to particular wealthy individuals that can absorb losses and own a vineyard for lifestyle reasons.

Previous research on clusters that include, but are not restricted to wine, highlight various forms of inter-firm cooperation (Dana \& Winstone, 2008; Dana et al., 2013; Felzensztein \& Deans, 2013; Felzensztein et al., 2014; 2018; 2019; Letaifa \& Rabeau, 2014; Geldes et al., 2015). In fact, some clusters are dense in comparison to others (Letaifa \& Rabeau, 2014; Geldes et al., 2015) so relationships vary in terms of geographic proximities and in particular cases, their associated social proximities of network ties. In the specific context of wine clusters, potential collaboration in respect of resources and capabilities varies (Haywood \& Lewis, 2008; Alonso, 2009; Charters \& Michaux, 2014; Felzensztein \& Deans, 2013; Felzensztein et al., 2014; Crick, 2018a). In terms of capabilities, an example from this earlier literature includes knowledge sharing to enhance a cluster's reputation (Crick, 2018a). Regarding resources, earlier examples include equipment sharing and joint promotions as cost saving mechanisms; also, cross referrals of cellar doors, restaurants, accommodation, and wedding venues; all to attract tourists to an area for mutual advantage (Dana et al., 2013; Crick, 2018a). Nevertheless, the extent of such practices 
may vary in line with business models in respect of wine and tourism, domestically and overseas (Felzensztein et al., 2014; 2019; Crick \& Crick, 2015).

\section{Dark-Side Practices}

Moving from the largely established positive relationship between coopetition and performance under the RBV in order to contribute to knowledge, the potential dark-side of relationships remains under-researched. In respect of the broader marketing literature, earlier research has emphasised the utility of employees engaging with customers to improve their respective firm's value provision to create or even co-create a positive experience (Hollebeek \& Brodie, 2009; Edvardsson et al., 2011; Alves et al., 2016; Yu et al., 2018). By interacting with customers, employees potentially gain experience regarding factors of perceived value; as such, they can adapt marketing strategies towards the issues that customers require (Payne et al., 2008; O'Cass \& Ngo, 2011).

However, a potential remains for what has been termed 'dark-side' behaviour; an issue relevant to this current investigation since employees' interactions with customers may not support the coopetition-oriented mind-set of owner-managers. Earlier marketing literature outside of coopetition activities considers dark-side behaviour within and outside organisations; also, being undertaken by customers, employees, or both (Harris \& Reynolds, 2003; Harris \& Ogbonna, 2006; Reynolds \& Harris, 2009; Daunt \& Harris, 2014; Daunt \& Greer, 2015). In the context of this current investigation, the previously mentioned tensions may arise in coopetition that can affect behaviour. Tidstrom (2014) suggests different tensions result in specific outcomes and hence management of coopetition is necessary; it may be a function of various roles, knowledge, power and dependence, plus opportunism. Raza-Ullah et al (2014) consider tensions at individual, organisational and 
inter-organisational levels. They discuss external and internal boundaries, like unifying forces and divergent forces and tensions via emotions occurring in different levels of persistence and intensity in various contexts. Virtanen \& Kock (2016) highlight that the nature of tensions within relationships may change based on the product-market strategies employed, as some collaborating firms will be in greater degrees of competition in comparison to others.

\section{Strategy as Practice}

Debate exists on the utility of the strategy as practice perspective (Whittington, 1996; 2006; Jarzabkowski et al., 2007; Burgelman et al., 2018; Jarzabkowski \& Bednarek, 2018). Nevertheless, it is emphasised in this current study that the approach undertaken did not set out to compare what owner-managers say and do, but rather what front line employees do in implementing the stated strategies of the owner-managers into practice. Whittington (1996, p. 731) suggests: "the focus of the approach undertaken is on strategy as a social 'practice', on how the practitioners of strategy really act and interact". What is relevant about this view towards this current investigation is that it does not locate the strategy of practitioners exclusively at the top of the organisation; instead, practitioners can be present at each level of the organisation.

The approach taken in this current study is to some extent consistent with a microfoundations research approach. That is, in the sense that different perspectives are taken to deconstruct a macro-level factor, namely coopetition in this investigation, into actions and interactions of staff in different areas of organisations' hierarchies (Barney \& Felin, 2013; Felin et al., 2015). However, in relatively small firms such as those in the NZ wine sector, the number of employees and therefore layers of hierarchy tend to be somewhat 
flat (Crick \& Crick, 2015). Therefore, interest in the role of the marketing function is limited to only a comparison of what owner-managers stated with what front-line employees actually did as opposed to multiple hierarchies or the views of decision-makers in a formal Marketing Department, more typical of larger firms.

\section{Research Focus}

Johnson et al. (2003) suggest that while aspects of strategy have traditionally be focused on the macro-level of organisations, research needs to also consider micro-level phenomena; that is, consistent with the micro-foundations perspective (Barney \& Felin, 2013; Felin et al., 2015). Consequently, this current investigation considers an 'adapted' strategy as practice perspective (as per Whittington, 1996; 2006; Jarzabkowski et al., 2007; Burgelman et al., 2018; Jarzabkowski \& Bednarek, 2018). Although coopetition can exist at the macro and micro levels, it is possible that strategies are formulated by key decision-makers to the advantage of their firm and other businesses in their respective cluster in the NZ wine sector; that is, a win/win situation. In contrast, implementing operational issues in respect of coopetition, such as day-to-day interactions in a regional cluster (like cellar door sales) is likely to take place via other employees working at the customer interface. Given the recognition of potential tensions (Fernandez et al., 2014; Raza-Ullah, et al., 2014; Tidstrom, 2014; Bengtsson et al., 2016) consistent with existing literature concerning the dark-side of marketing, it follows that coopetition activities may not always be handled by those working at the customer interface in a way consistent with that of the key decision makers' strategies; hence, opportunistic behaviour may potentially occur. 
As noted by Virtanen \& Kock (2016), the scope of the firms' portfolio of business activities in terms of product-market strategies might affect coopetition practices. In the case of the wine sector, this can involve the production of wine and related tourism that in the latter includes cellar door activities (Crick \& Crick, 2015). Sharing of different resources/capabilities are likely to take place consistent with the RBV to enhance network partners' performance depending on the nature of their activities (product-market strategies). Research data that includes interviews with, and observation of, practitioners at different levels of firms, can shed more light on our understanding of the coopetition paradox. It is worth repeating this study's research question before consideration of the research methods undertaken as follows: to what extent are practices at the customer interface consistent with decision-makers' coopetition strategies?

\section{Methods}

\section{Concepts and Measurement}

Decisions regarding concepts and their measurement followed a review of the existing literature and exploratory interviews. First, the previously mentioned definition by Bengtsson \& Kock (2014) was utilised for coopetition involving the paradoxical interplay between cooperation and competition. Measurement of coopetition was via interviews with owner-managers and Cellar Door Managers, together with observation of employees at cellar doors to determine if employee behaviour with customers was in line with managerial comments at the interview stage. Second, conceptualisation of organisational performance has varied in earlier studies in the broader marketing literature and coopetition-oriented research using objective and subjective measures; for example, sales performance, competitive advantages, market-level survival, and customer satisfaction (Ang, 2008; Ritala, 2012; Le Roy \& Sanou, 2014; Katsikeas et al., 2016; Crick, 2019a). 
Sales performance was the utilised measure via decision-makers' perceptions of meeting objectives over a period of 3 years to allow time for the effect of coopetition oriented behaviour to be determined. Measurement of performance was established via interviews with owner-managers in respect of coopetition-oriented activities.

\section{Data Collection}

The boundary of this study (Stake, 1995) involved vineyards in NZ. Interviews took place in 25 smaller-sized and independently owned, vineyards; ownership was important to avoid bias associated with parent company involvement. In total, the study involved 38 interviews lasting approximately 60 minutes, within the 25 firms; this data collection comprised of the perceptions of owner-managers as key decision makers and Cellar Door Managers for different perspectives regarding the research question. Twelve vineyards did not have different employees working at cellar doors so only the owner-managers' perceptions in those firms feature in this study for background purposes on coopetitionoriented practices. Therefore, for clarity, separate interviews with a manager working at the cellar door took place in 13 firms. Selected characteristics of the vineyards are contained in Table 1. Firms within the sample were subjectively classified (following owner-managers' interviewee data) in accordance with the 4 cells in Table 2, namely the 'Product Portfolio-Coopetition Matrix' (adapted from Crick, 2015). Classification represents first, the degree of coopetition owner-managers considered that they engaged in; second, the degree to which owner-managers considered their firm engaged in core wine sales as opposed to wider tourism that included the cellar door sales through to restaurants, accommodation etc. The latter was important since firms with different portfolios may collaborate and compete in different ways; that is, in respect of wine as opposed to 
tourism (product-market strategies in line with Virtanen \& Kock, 2016). Subjective labels to describe the firms in the 'Product Portfolio-Coopetition Matrix' follow.

Product Focus - These organisations engage in limited coopetition, since their operations are often concentrated on their core 'product' (wine in the current study). They employ an individualistic business model that requires limited assistance from rivals. As they are generally smaller firms, they often have a narrow portfolio, in which offering services (like wine tourism) would be a hindrance and potentially costly.

Community Service - Firms engage in high-levels of coopetition within their local 'community'/cluster to recognise the mutually-beneficial outcomes of collaborating with competitors. They are typically smaller organisations that have a narrow product portfolio, with few augmented services. For such firms, it could be expensive and time-consuming to offer additional services that they cannot sufficiently manage.

Service Focus - These companies generally focus on their own customer 'service' operations and operate an individualistic business model, hence, do not have a strong desire to engage in coopetition strategies. However, as these businesses are typically larger in size, they have the resources and capabilities to offer an augmented product/service portfolio to create value for their own customers.

Team Player - Businesses are part of a 'team' and involved with a variety of network partners. They engage in high-degrees of coopetition because they recognise the benefits of acquiring new resources, capabilities, and opportunities from industry rivals. Furthermore, these firms offer a wide array of products and services, as they typically 
have enhanced tangible and intangible assets to allow them to manage an augmented product portfolio.

\section{Insert Tables 1 and 2 Here}

Observations took place at the previously mentioned 13 cellar doors that in certain cases also included sales of gifts and food as part of an extended product portfolio outside of core wine sales. The idea was to establish whether implementation of what ownermanagers claimed actually occurred in practice regarding employees' performanceenhancing coopetition behaviour with customers. In respect of observational research, key issues involve 'what is observed' and 'how'? Field notes of customer interactions rather than digital recordings feature in this study and recognition exists that the approach offered a potential degree of bias. Nevertheless, there was no application for ethics approval regarding overt video or tape recording since it was unlikely owner-managers would allow overt recording at the vineyard; also, it might influence employees' behaviour. Due to the cost of travel to various wine clusters, observation was limited to a morning or afternoon rather than an extended period, hence providing a restriction on data collection.

Since assurance of anonymity to participants in this investigation took place, no mention of their names or firms feature in Table 1. Furthermore, since the wine industry in NZ is relatively small, there is an avoidance of certain background data associated with firms so not to identify specific vineyards. In particular, to avoid a breach of ethics in terms of revealing identities of those in which observation of aspects of dark-side marketing practices took place. Nevertheless, no firms were observed in the 'Product Focus' (narrow portfolio and low coopetition) cell of Table 2, since the interviews with the owner-managers suggested by the very nature of their categorisation, that there would be nothing to observe in the context of this study. For the 'Team Players' that exhibited an augmented 
product portfolio and a high degree of coopetition, employee interactions with customers in 5 firms were observed, with 4 each in the remaining 2 categories/cells.

The New Zealand Wine Growers Association holds a database of members representing growers of grapes plus wine producers. From this, a purposive sample took place of wine producing vineyards, namely wineries, since those that only act as growers of the grapes and that do not produce their own wine, are important, but nonetheless, form only part of the supply chain. Recognition featured in this study of the concern of Beverland \& Lindgreen (2010), namely, in respect of the challenge of arriving at the number of cases that achieves a balance between theoretical saturation and cross-case comparison. The researchers discontinued data collection after they agreed reaching a point of diseconomies of finding new information. The previously mentioned sample represented wine producers (referred to in this current study as 'vineyards' to reflect practitioner discourse) from different clusters/regions of NZ. Participants specialised in particular wines, namely, both white and red varieties and operated various product portfolios (including wine tourism). This data collection approach was important to establish how coopetition existed across the boundary of the study. Interviews were also undertaken with 2 people with responsibility for promoting wine in specific regions of New Zealand; also, a director of the New Zealand Wine Growers Association. These supplementary interviews avoided reference to specific firms due to confidentiality, but provided further contextual data regarding aspects of coopetition. Textual data in the form of reports, websites etc. were also utilised where possible; that is, regarding the firms themselves and issues associated with the sector. However, this study focuses on owner-managers' and employees' perceptions and observed behaviour of the latter. 


\section{Data Analysis}

Use of qualitative research and more specifically the process followed in developing case studies has received criticism in recent studies (Beverland \& Lindgreen, 2010; Piekkari et al., 2010). No claim is made of case study research in this current investigation, as thick description of the practices within individual firms did not feature as an objective. The approach undertaken builds on the work of Stake (1995) and considers 'issues' of importance to the specific research question outlined earlier. Maintaining the credibility and trustworthiness of the data took place (Guba \& Lincoln, 1994; Morrow, 2005; Sinkovics \& Alfoldi, 2012) where possible. The approach took account of the context, narratives and personal engagement undertaken. What might be termed 'particularization' featured in this study, since the nature of coopetition strategies varied among firms participating; hence, the research approach recognised that establishing cause-effect relationships is simplistic.

Rather, an appreciation of the social context is important (Tadajewski, 2010) and use is made of quotes where possible to add practitioner discourse. Manual coding took place via a process of data reduction utilising within-and between-case analyses; that is, the term 'cases' referring to firms and not case studies. Utilisation of 'progressive focusing' was undertaken in line with the recommendations of Sinkovics \& Alfoldi (2012) to focus on key issues related to the research question. Derived themes from patterns and relationships within the data and iteration with the existing literature feature in this study. Consideration of these themes took place independently and subsequently were discussed collectively by the researchers. This process enabled potential explanations of 'what' as well as 'how' and 'why' certain aspects of behaviour occurred. 


\section{Findings}

Overview

From the outset, it is important to highlight that progressive focusing during the data analysis indicated that all owner-managers perceived coopetition within their cluster facilitated them meeting their performance objectives. Therefore, it is again emphasised that the relationship between resources/capabilities sharing and performance is not the explicit focus of this current investigation as earlier research establishes this. More important, is the interviewees indicated that the nature of coopetition in enhancing performance varied between product-market strategies employed. Owner-managers discussed issues such as sharing knowledge, equipment and engaging in joint promotional activities between rival firms. However, limited consideration is given to international wine sales, since this current study focuses on coopetition behaviour in the cluster-based domestic NZ market, given that employee interactions with customers could only be observed in that context. Some vineyards concentrated on wine sales and tourism related to cellar door sales, while others offered a more diversified portfolio. In the former, particular vineyards concentrated on different varietals of wine. In the latter, this was in respect of wider tourism-hospitality issues where different portfolios also meant some firms were not direct competitors in certain regards. For example, particular firms had a restaurant and others did not or catered for different parts of the market such as coffee/snacks rather than full-service meals. As such, the findings that follow are in respect of firms' classification in Table 2.

\section{Cell 1 - Product Focus}

As previously mentioned in the Methods section, observation did not take place regarding firms in this cell because the interviews with the owner-managers suggested by the very 
nature of their classification, that there would be nothing to observe in respect of the research question. These vineyards concentrated on the production of wine rather than having a greater involvement in the broader hospitality-tourism area. Perceptions towards collaboration with competing vineyards was limited, since decision-makers considered there was a limited need to engage in issues related to hospitality and tourism with the exception of being part of organised wine tours for their limited sales in this regard.

However, in terms of the core wine production, the collaborative nature of the sector meant that the owner-managers were sometimes willing to let other vineyards borrow equipment. On day-to-day matters, they largely possessed what resources they needed and coopetition was via goodwill as owner-managers were typically friendly with counterparts in competing vineyards. As one interviewee commented: "we all know each other and I try to help". There was an incentive for a degree of collaboration in respect of sharing of knowledge to avoid the circumstances where a vineyard within a cluster did not "go rogue" and produce poor quality wine to the detriment of the reputation of other firms in the cluster. An interviewee suggested in relation to the cluster: "if a firm produces wine that tastes like $p^{\star *}$ s we all suffer".

Another interviewee highlighted individual aspects of competition and collaboration, for example, joint promotions at an international-level, as this was more important than at a regional level given the focus on wine sales rather than a wider tourism related portfolio. "If a customer wants Italian or French wine then they are not going to buy New Zealand wine. We are competing against other New Zealand wine and since we are doing so well I think we have demonstrated our ability to be seen as different". A further interviewee continued the international theme in the preceding quote and suggested that collaboration took place in joint initiatives for export markets to save costs, for example, through the New Zealand 
Wine Growers Association. The interviewee noted that coopetition only exists up to a point, such as, joint promotions: "exports are important to us (his firm) and therefore with New Zealand wine taking such a small share of global sales I am trying to get my wine sold over competitors. I am happy to consider anything that helps my firm".

\section{Cell 2 - Community Service}

Similar to the first cell, firms had a limited portfolio that focused on wine sales and these were often via distributors other than those at the cellar door. However, in contrast, they engaged in a relatively high degree of coopetition. Their reasons for engaging in the sharing of knowledge were consistent with the first group and in particular, so a rival vineyard did not produce poor quality wine that negatively affected the reputation of the cluster. Nevertheless, owner-managers typically were more open to lending and borrowing equipment than the first group. One owner-manager was relatively new to the sector and commented: "I am working really hard to get myself known and you cannot underestimate the importance of who you know and not just what you know". Knowledge was important and he added "you don't know what you don't know when you start!" The interviewee proceeded to add "it is so important to build relationships when you own a vineyard, but for me at the moment, it is not just what I don't know it's also who I don't know. For example, making sure the tour groups include us. If we get missed out it will affect us badly (regarding cellar door sales)."

A collaborative mind-set was representative of the other owner-managers interviewed in this cell and that establishment regarding the duration and quality of network relationships in the sector took place in certain cases over a number of years. During the interviews with managers at the cellar doors, a collaborative mind-set was evident. For example, one 
commented: "I enjoy finding out what works and doesn't work at other vineyards. I introduce myself when I visit and I am starting to see people around... Tours can only cover so many vineyards in a morning or a day so my main priority has been to look after the tour groups when they come and make sure that by working with others they visit us since they have so much choice". None of the cellar door staff in this cell had received formal training and had learnt on the job; as one interviewee commented: "I just picked up things as I went along".

However, observations in all firms in this cell established degrees of questionable or at the very least unhelpful (dark-side) behaviour. In all of these firms, customers received limited recommendations towards other vineyards or they were even put off visiting other vineyards; for example, subtle comments like "oh, their wine might be too sweet for you", or in relation to varietal ' $\mathrm{X}$ ', "our wine has won awards over theirs". Observations of darkside behaviour extended to specific comments such as: "they have been having some problems" without saying what those problems were. In short, no observations took place of overtly derogatory comments that could come back to affect the cellar door staff in a legal sense regarding other competing vineyards. Instead, the examples from observations gave an indication of approaches used to influence customers not to visit directly competing vineyards despite the owner-managers and the Cellar Door Managers claiming in the interviews that their firms had engaged in a high degree of coopetition.

There was limited customer co-creation of the service experience observed in any of the firms in this cell, like to get to know about visitors' experiences, where else they had been, where they were still to go, etc. A key focus seemed to be selling the wine with opening remarks such as "we have ' $X$ ' on special today" or a similar direct comment with limited 
customer rapport. Nevertheless, if asked directly, cellar door staff provided recommendations in respect of non-competing factors within vineyards, for example, in relation to those vineyards with augmented product portfolios such as restaurants. Observations suggested that cellar door staff were very knowledgeable and helpful in referring customers to vineyards that offered coffee/snacks, full-service restaurants, or even with accommodation that their own vineyards did not offer. Furthermore, those that sold different varietals of wine to those sold by their own firm. Even in the event recommendations occurred, these were limited to neighbouring vineyards in geographically dispersed clusters as opposed to those further away in the cluster. This was interesting as it suggested a degree of coopetition only with vineyards in which combined geographic and social proximity ties were strongest rather than the cluster as a whole.

\section{Cell 3 - Service Focus}

Firms in this cell had an augmented product portfolio and a low level of coopetition. Consistent with interviewees in the two earlier cells, their reasons for sharing of knowledge were consistent and primarily so a rival did not produce poor quality wine that might negatively affect the reputation of the cluster. There was typically not a perceived need to borrow or lend equipment as they had what they needed. Owner-managers believed that there was a limited need to collaborate except for major expenses, such as, pooling resources for shared promotions. For example, one commented: "why would customers attend a wine promotion involving just us? However, if a group of us came together, put on food and made an event of it then that would be more appealing so customers could experience a variety of wines". 
As with firms in cell 2, none of the cellar door staff had received formal training. The interviews with Cellar Door Managers echoed the comments of owner-managers and especially as they might be working at the cluster's promotional events, where there was a degree of collaboration with competitors. However, there was a common belief among the interviewees that despite the pooling of resources, events would be otherwise competitive. As one interviewee explained: "we need to get customers to the area and joint promotions are good for that. Then we need to get them spending with us rather than at other vineyards". Another commented: "we have a restaurant so we need to put on good service because if we treat customers badly or the food is crap they may not buy our wine either on the day or in the future". A different interviewee at the cellar door commented: "the region is fairly small and we all know each other, but business is business, and if there is only so much to go round I would rather it come to us!" In short, coopetition existed, but only up to a point when competitiveness was greater than collaboration.

Similar to firms in cell 2, observations in all firms established degrees of questionable or at least unhelpful (dark-side) behaviour. In all firms in this cell, there was limited customer co-creation of the service experience in order to get to know about the visitors. In fact, customers received limited recommendations to other vineyards or were discouraged from visiting them; instead, regarding employee/customer service interactions, being actively steered to employees' own specific extended portfolio within their firm. For example, their firm's coffee area through to restaurant to keep customers on site with the potential view to gain further sales. This involved subtle comments like "they (rival firm) have a limited menu", or "we have a trained barista", or "our restaurant is mentioned on Tripadvisor". 
Again similar to cell 2, negative comments in all firms also extended to those of a more specific nature such as: "our customers have had a bad experience there (named vineyard)" without saying what the bad experience involved. Nevertheless, no observed overtly derogatory comments took place in a legal sense that could come back at the cellar door staff regarding other competing vineyards. In all of the firms in this cell, observation occurred of certain negative comments from customers following their service encounter at the cellar door. For example, in one vineyard there were instances of customers making negative comments like "he was a miserable....." or "he was unhelpful" plus "that was a hard sell". In 3 firms there were examples of customers actively making comments like: "I would not go back there".

\section{Cell 4 - Team Player}

Firms in this cell exhibited a high degree of coopetition and an augmented product portfolio. All owner-managers were consistent in claiming the importance of cooperation in the sector and discussed various unforeseen issues that can arise. As one interviewee commented: "you know machinery will break down at some time, the weather may be bad, something nasty (meaning bacteria or similar) may damage the vines, then there was the financial crash and I could go on. What you can do is realise it is a matter of time before these things will happen one day and do your best to plan for them. That is partly why the industry works so well together because some of the things I mentioned can affect others as well as your own business". Coopetition at the cluster level was important to ownermanagers in this cell and as one commented: "we want people to come to the area so everyone benefits. We are happy to help other vineyards and they come to see what we do - we have even lent some of them our equipment. If our time comes I hope they will help us". As with firms in the other 3 cells, there was a common need for sharing 
knowledge to stop a vineyard from producing poor wine to the detriment of the cluster's reputation.

Coopetition at a cluster level was evident for firms in this cell via use of both business and social networks that in some cases overlapped. A common issue was the extent to which in certain clusters the area was relatively small and as one owner-manager summed up: "we see each other (members of rival vineyards) and stop for a chat about how things are going in the shops and cafes all the time, let alone the trade events". This led to leadership in advancing a cluster's interests as noted by a different owner-manager "I try to get myself on various boards so I can influence the agenda for the region". However, in furthering shared interests in their cluster, another commented: "we share knowledge and equipment all the time". As a further owner-manager mentioned: "even the winemakers at the different vineyards share some knowledge and they see each other at various events it's a small community in New Zealand let alone in this region. If we want our region to be known for Pinot Noir then we all (competing firms) benefit if our reputation increases and so do sales and the price points at which we charge".

Interviews with Cellar Door Managers echoed the views of the owner-managers. It was interesting that no negative observations were apparent in any of the firms in cell 4 ; it appeared that owner-managers had provided at least the basic training and/or set expectations. Monitoring took place so behaviour at the cellar doors was consistent with their desired strategies. Unlike cellar door employees in cells 2 and 3, observation of knowledge regarding, and positive behaviour towards, other vineyards' portfolios of business operations took place among cellar door staff in cell 4. Furthermore, one Cellar Door Manager commented: "I know their (competitors') wines and might recommend customers to go to different vineyards for a type of wine that may be sweeter or more like 
our own. I also know what else they offer so I can say things like - after us why not go to (name of firm with-held) as they have a great restaurant, or I might suggest another that just does antipasto. They will be doing the same for us because we all benefit as people come to the area and have a great experience and recommend others or even come back themselves"...The interviewer asks "why not recommend your own restaurant?"... Answer: "we do but let's say the person is staying a few nights and will eat in our restaurant one night but may want to go elsewhere for a different experience the next night or at lunch then come back to us on the last night. So coming back to the question, yes collaboration is important and it is all about trying to get the best experience for the customers so people come back or recommend others to bring money to the area and we all benefit".

The extent that owner-managers (as decision-makers) were involved at the customer interface varied, for example, one owner-manager commented: "I sometimes work the cellar door myself", whereas another was only involved in key decision-making and stated the lack of involvement at the cellar door was because: "I don't want to be intrusive". However, that same owner-manager proceeded to mention that: "I get regular feedback from customers about the service received from my staff". It was clear that these ownermanagers maintained service standards at the cellar door, an issue not observed in cells 2 and 3. All interviewees managing the cellar door sales in cell 4 claimed they were aware of what their rival firms were doing locally. However, the extent to which cellar door employees were actively encouraged to visit and learn from others varied with one saying that: "I pay myself to try wine or eat at other vineyards". All visited rival vineyards but reasons for the visits varied. These ranged from those interviewees that perceived this would assist them to learn good and bad practices to help in their own jobs through to 
those that mentioned aspects of coopetition (without using the explicit term in the practitioner discourse).

One Cellar Door Manager commented about negative practices observed elsewhere. "It is really interesting to observe staff in other places (rival vineyards) and I remember one telling a customer to take their hat off as it had the logo of a competing firm; I could not believe this"... The interviewer asks - "do your competitors know who you are or rather who you work for?".... Answer: "most do as it is a small community and unless there is a new person working I know most people". Another commented: "I always want to learn. I like to know the types of wines offered by other vineyards even if they are dry or sweet so I can advise customers where else they can go for similar or different tastes to our own". An interesting point was raised by 2 interviewees in this cell that may explain observed behaviour in cells 2 and 3; this is summed up by the following comment. "You need to remember that some of the vineyards that offer bad service are staffed by people that are not on long-term contracts and are paid a minimum wage with bonuses based on how much they sell!"

\section{Summary}

The research question in this study involved the following, namely, to what extent are practices at the customer interface consistent with decision-makers' coopetition strategies? It is therefore worth revisiting the earlier quote that Kraft (1991, p. 485) borrows from earlier research. "There may be some inconsistencies between what managers say, and what they do". In this current investigation, the issue related to potential dark-side marketing practices leading to inconsistencies between what ownermanagers say and what their front line employees do. Underpinned by the RBV, this 
current investigation builds on the resources-performance enhancing relationship proposed in earlier research (Barney, 1991; 2001). It extends knowledge of the Relational View within the RBV, taking account of the quality of network relationships (Dyer \& Singh, 1998; Dyer et al., 2018) and notes the role of stakeholders (Barney, 2018). Recognition exists in this current study of the competitive business environment (Priem \& Butler, 2001) affecting certain wine clusters (Felzensztein \& Deans, 2013; Felzensztein et al., 2014; 2018; 2019; Crick, 2018a; 2018b; Granata et al., 2018). Specifically, recognition exists in earlier studies that accessing resources and capabilities from competitors can lead to performance-enhancing relationships in underresourced firms operating within competitive business clusters (Crick, 2018a; Felzensztein et al., 2018; Granata et al., 2018).

In helping to transcend the potential coopetition paradox (Fernandez et al., 2014; RazaUllah, et al., 2014; Tidstrom, 2014; Bengtsson et al., 2016), this study employed an 'adapted' strategy as practice perspective among firms engaged in coopetition within the NZ wine industry (Whittington, 1996; 2006; Jarzabkowski et al., 2007). It was previously emphasised in this study that the approach undertaken did not set out to compare what owner-managers say and do, but rather what front line employees do when implementing the stated coopetition strategies of the owner-managers into practice. The rationale was to contribute to the literature on the dark-side of marketing involving aspects of unwanted and undesirable behaviour that in certain cases may be detrimental to businesses (Harris \& Daunt, 2011; Daunt \& Harris, 2014; Daunt \& Greer, 2015; Greer, 2015). This is important given that Grönroos (1990) notes the importance of the relational approach to service contexts; moreover, outside of the notion of coopetition, the issue of trust in relationships is recognised as important (Sekhon et al., 2014). 
Existing studies have investigated various product-market strategies such as core wine sales domestically and overseas together with domestic tourism activities (Haywood \& Lewis, 2008; Charters \& Michaux, 2014; Felzensztein \& Deans, 2013; Felzensztein et al., 2014; Crick, 2018). Consequently, a 2x2 matrix (Table 2) was utilised in this current investigation to investigate the practices of NZ vineyards employing narrow and augmented product portfolios together with low and high levels of coopetition. No observations took place in cell 1 (Product Focus) of Table 2 as there would be nothing to observe due to the way firms were classified. Furthermore, in cell 4 (Team Player), employee behaviour was consistent with owner-managers' perceptions. In contributing to knowledge regarding the resources-performance enhancing relationship of coopetition, the observational findings of this study suggested that certain customer interactions at the cellar door contrasted with the interview data (cells 2 and 3). As such, this current study adds to our understanding of aspects of the dark-side of marketing practices in respect of inter-firm relationships.

\section{Conclusions}

The first conclusion is that in competitive environments, the resource-performance relationship of the RBV only goes so far in certain firms' coopetition strategies. In this current study, an example involves particular cellar door employees varying in the extent to which they actually implemented owner-managers' desired coopetition strategy into practice; that is, some less well trained staff having degrees of 'deviant' (dark-side) behaviour in cells 2 and 3 of Table 2. The related second conclusion is that appropriate recruitment, training and incentives are important with respect to front line employees in a services marketing environment. Specifically, so owner-managers' desired strategies are indeed implemented into practice. In this current study, demonstration of consistent 
behaviour among employees in cell 4 (Team Player) of Table 2 serves as an example. Front line staff undertook coopetition activities to gain some perceived co-created value to enhance performance, for example, cross-referrals for a win/win situation among firms. The related third conclusion is that tensions arising from the potential coopetition paradox under investigation need managing (Fernandez et al., 2014; Raza-Ullah et al, 2014; Tidstrom, 2014). That is, in cell 4, there was a general recognition in the firms' corporate cultures (such as via training) of the need for coopetition to occur in the cluster for mutual performance benefit among vineyards that was not evident among employees within firms in cells 2 and 3 of Table 2.

Moreover, consistent with the categorisation of firms across the cells in Table 2 , the fourth conclusion is that coopetition can manifest differently across businesses operating various product-market strategies (Virtanen \& Kock, 2016). Specifically, across certain geographic markets, the product portfolio involved could include the wine itself and/or the hospitalitytourism aspects of certain vineyards hosting wine tours, weddings; having restaurants etc. (Haywood \& Lewis, 2008; Charters \& Michaux, 2014; Crick \& Crick, 2015). Such considerations are important in this current investigation given that firms need to maintain the reputation of a cluster not just in terms of the perceived quality of brands, but also the service experience associated with tourism activities, like facilitating repeat visits to clusters. This is a win/win situation for reciprocating firms.

While interviewees recognised such benefits, observations of certain untrained and less motivated cellar door staff in cells 2 and 3 of Table 2 took place. Specifically, examples occurred of employees actively directing customers away from competitors' vineyards, failing to engage in collaborative service activities, and even when they made recommendations about competitors, these were typically to neighbouring vineyards. Such 
dark-side employee behaviour runs contrary to the Relational View of the RBV, irrespective of the competitive nature of business environments. In other words, the resource-enhancing relational advantages of coopetition to assist performance among firms recognised by owner-managers did not always translate as a strategy in practice among front line employees, depending on the product-market served.

\section{Managerial Implications}

This study is important since some dark-side practices have implications for the way owner-managers that engage in coopetition, recruit, train and incentivise front line employees that interact with customers. In fact, observations suggest certain employees' service behaviour was subtle, but still unhelpful, in potentially bringing back repeat custom or even increasing tourism to regional clusters that may affect sales. Within a competitive environment typified by certain clusters, it is likely that coopetition-oriented benefits will be evident for owner-managers that are able to operate a corresponding business model to enhance performance. In small clusters, it is likely that decision-makers in competing firms will know each other to varying degrees. Those that can work together in sharing resources/capabilities (including knowledge) for a mutual advantage need to set expectations, plus manage relationships via recruitment, training and regular communication with their employees. This is especially important for part-time and shortterm contract staff that may be motivated by bonuses based on sales whereby they have a potential self-interest in meeting their own rather than the wider cluster's interests.

In the case of the wine sector and in particular NZ's clusters that formed the boundary of this study, with downturns likely over time in particular economies, reduced consumer spending might affect purchases of firms' core wine products; this may also influence 
tourists visiting wineries. It is important that decision-makers enable staff, like those at the cellar door, to be correctly 'incentivised' and fully trained in order to provide value-added service encounters in coopetition activities. In certain clusters, this may mean a worthwhile investment in funding visits, for example, knowing what peers in other firms are doing, not doing, and what enhancement can take place regarding value-added services within their coopetition relationships. Employees can learn best practices together with avoiding deviant (dark-side) practices for a mutual advantage, such as, via cross-referrals.

\section{Limitations and Future Research}

This study has some limitations and not least that the study took place within a single sector and country context. Furthermore, only a limited number of observations were undertaken and these were time constrained. The limitations provide a foundation on which other researchers can build in extending our understanding of coopetition-oriented decision-making to enhance customer service experiences and performance in different sector and country contexts. This includes potentially utilising a strategy as practice perspective for qualitative insights and/or quantitative studies employing statistical analysis for greater generalisability. Future studies need to further address overcoming tensions to avoid practices at the dark-side of marketing. Context may be important and studies in various sectors that have their own norms of operation help extend our understanding of practices in order to bridge the gap in knowledge regarding the seemingly paradoxical nature of coopetition practices. 


\section{References}

Alonso, A.D. (2009). Are travellers interested in wine tourism in New Zealand? International Journal of Culture, Tourism and Hospitality Research, 3 (1), 13-24.

Alves, H., Fernandes, C. \& Raposo, M. (2016). Value co-creation: Concept and contexts of application and study. Journal of Business Research, 69 (5), 1626-1653.

Ang, S.H. (2008). Competitive intensity and collaboration: Impact on firm growth across technological environments. Strategic Management Journal, 29 (10), 1057-1075.

Arslan, B. (2018). The interplay of competitive and cooperative behavior and differential benefits in alliances. Strategic Management Journal, 39 (12), 3222-3246.

Barney, J.B. (1991). Firm resources and sustained competitive advantage. Journal of Management, 17 (1), 99-120.

Barney, J.B. (2001). Is the resource-based view a useful perspective for strategic management research? Yes. Academy of Management Review, 26 (1), 41-56.

Barney, J.B. (2014). How marketing scholars might help address issues in resource-based theory. Journal of the Academy of Marketing Science, 42 (1), 24-26.

Barney, J.B. (2018). Why resource-based theory's model of profit appropriation must incorporate a stakeholder perspective. Strategic Management Journal, 39 (13), 33053325.

Barney, J. \& Felin, T. (2013). What are microfoundations? Academy of Management Perspectives, 27 (2), 138-155.

Bengtsson, M. \& Kock, S. (2000). "Coopetition" in business networks - to cooperate and compete simultaneously. Industrial Marketing Management, 29 (5), 411-426.

Bengtsson, M. \& Kock, S. (2014). Coopetition-quo vadis? Past accomplishments and future challenges. Industrial Marketing Management, 43 (1), 180-188. 
Bengtsson, M. \& Raza-Ullah, T. (2016). A systematic review of research on coopetition: Toward a multi-level understanding. Industrial Marketing Management, 57 (1), 23-39.

Bengtsson, M., Raza-Ullah, T. \& Vanyushyn, V. (2016). The coopetition paradox and tension: The moderating role of coopetition capability. Industrial Marketing Management, 53 (1), 19-30.

Beverland, M. (2004). Uncovering theories in-use: Building luxury wine brands. European Journal of Marketing, 38 (3-4), 446-466.

Beverland, M. \& Lindgreen, A. (2010). What makes a good case study? A positivist review of qualitative case research published in Industrial Marketing Management, 1971-2006. Industrial Marketing Management, 39 (1), 56-63.

Bouncken, R.B., Fredrich, V., Ritala, P. \& Kraus, S. (2018). Coopetition in new product development alliances: Advantages and tensions for incremental and radical innovation. British Journal of Management, 29 (3), 391-410.

Bruwer, J. \& Beller, C. (2012). Country-of-origin (COO) brand preferences and associated knowledge levels of Japanese wine consumers. Journal of Product \& Brand Management, 21 (5), 307-316.

Burgelman, R.A., Floyd, S.W., Laamanen, T., Mantere, S., Vaara, E. \& Whittington, R. (2018). Strategy processes and practices: Dialogues and intersections. Strategic Management Journal, 39 (3), 531-558.

Charters, S. \& Michaux, V. (2014). Strategies for wine territories and clusters: Why focus on territorial governance and branding? Journal of Wine Research, 25 (1), 1-4.

Combs, J.G. \& Ketchen Jr, D.J. (1999). Explaining inter-firm cooperation and performance: Toward a reconciliation of predictions from the resource-based view and organizational economics. Strategic Management Journal, 20 (9), 867-888. 
Crick, D. \& Crick, J. (2015). Learning and decision making in marketing planning: A study of New Zealand vineyards. Marketing Intelligence \& Planning, 33 (5), 707-732.

Crick, J.M. (2015). Bridging the Gap between Threshold and Dynamic Capabilities: A Qualitative Study of the Collaboration Strategies of New Zealand Wineries. Unpublished MBS thesis in Management. Massey University, New Zealand.

Crick, J.M. (2018a). The facets, antecedents and consequences of coopetition: An entrepreneurial marketing perspective. Qualitative Market Research: An International Journal, 21 (2), 253-272.

Crick, J.M. (2018b). Studying coopetition in a wine industry context: Directions for future research. International Journal of Wine Business Research, 30 (3), 366-371.

Crick, J.M. (2019a). Moderators affecting the relationship between coopetition and company performance. Journal of Business \& Industrial Marketing, 34 (2), 518-531.

Crick, J.M. (2019b). Incorporating coopetition into the entrepreneurial marketing literature: Directions for future research. Journal of Research in Marketing and Entrepreneurship (Available Earlycite).

Crick, J.M. and Crick, D. (2019). Developing and validating a multi-dimensional measure of coopetition. Journal of Business \& Industrial Marketing (Available Earlycite).

Dahl, J. (2014). Conceptualising coopetition as a process: An outline of change in cooperative and competitive interactions. Industrial Marketing Management, 43 (2), 272-279.

Dana, L-P., Granata, J., Lasch, F. \& Carnaby, A. (2013). The evolution of co-opetition in the Waipara wine cluster of New Zealand. Wine Economics and Policy, 2 (1), 42-49.

Dana, L-P. \& Winstone, K.E. (2008). Wine cluster formation in New Zealand: Operation, evolution and impact. International Journal of Food Science and Technology, 43 (12), 2177-2190. 
Daunt, K.L. \& Greer, D.A. (2015). Unpacking the perceived opportunity to misbehave. European Journal of Marketing, 49 (9/10), 1505-1526.

Daunt, K.L. \& Harris L.C. (2014). Linking employee and customer misbehaviour: The moderating role of past misdemeanours. Journal of Marketing Management, 30 (3/4), $221-244$

Deloitte (2017). Ripening opportunities. Wine industry benchmarking and insights 2017 New Zealand, www.deloitte.com.

Dyer, J.H. \& Singh, H. (1998). The relational view: Cooperative strategy and sources of inter-organizational competitive advantage. Academy of Management Review, 23 (4), 660-679.

Dyer, J.H., Singh, H., \& Hesterly, W.S. (2018). The relational view revisited: A dynamic perspective on value creation and value capture. Strategic Management Journal, 39 (12), 3140-3162.

Edvardsson, B., Tronvoll, B. \& Gruber, T. (2011). Expanding understanding of service exchange and value co-creation: A social construction approach. Journal of the Academy of Marketing Science, 39 (2), 327-339.

Felin, T., Foss, N.J. \& Ployhart, R.E. (2015). The microfoundations movement in strategy and organization theory. The Academy of Management Annals, 9 (1), 575-632.

Felzensztein, C. \& Deans, K.R. (2013). Marketing practices in wine clusters: Insights from Chile. Journal of Business \& Industrial Marketing, 28 (4), 357-367.

Felzensztein, C., Stringer, C., Benson-Rea, M. \& Freeman, S. (2014). International marketing strategies in industrial clusters: Insights from the Southern Hemisphere. Journal of Business Research, 67 (5), 837-846. 
Felzensztein, C., Gimmon, E. \& Deans, K. (2018). Coopetition in regional clusters: Keep calm and expect unexpected changes. Industrial Marketing Management, 69 (Feb), 116-124.

Felzensztein, C., Deans, K.D. \& Dana, L-P. (2019). Small firms in regional clusters: Local networks and internationalization in the Southern Hemisphere. Journal of Small Business Management, (Available Earlycite).

Fernandez, A-S., Le Roy, F. \& Gnyawali, D.R. (2014). Sources and management of tension in co-opetition case evidence from telecommunications satellites manufacturing in Europe. Industrial Marketing Management, 43 (2), 222-235.

Geldes, C., Felzensztein, C., Turkina, E \& Durand, A. (2015). How does proximity affect inter-firm marketing cooperation? A study of an agribusiness cluster. Journal of Business Research, 68 (2), 263-272.

Gnyawali, D.R. \& Charleton, T.R. (2018). Nuances in the interplay of competition and cooperation: Towards a theory of coopetition. Journal of Management, 44 (7), 25112534.

Gnyawali, D.R. \& Park, B-J. (2011). Co-opetition between giants: Collaboration and competitors for technological innovation. Research Policy, 40 (5), 650-663.

Granata, J., Lasch, F., Le Roy, F. \& Dana, L-P. (2018). How do micro-firms manage coopetition? A study of the wine sector in France. International Small Business Journal, 36 (3), 331-355.

Greer, D.A. (2015). Defective co-creation: Developing a typology of consumer dysfunction in professional services. European Journal of Marketing, 49 (1/2), 238-261.

Grönroos, C. (1990). Relationship approach to marketing in service contexts: The marketing and organizational behavior interface. Journal of Business Research, 20 (1), 3-11. 
Guba, E.G. \& Lincoln, Y.S. (1994). Competing paradigms in qualitative research. In N.K. Denzin \& Y.S. Lincoln (Eds.), Handbook of Qualitative Research, London: Sage.

Hannah, D.P. \& Eisenhardt, K.M. (2018). How firms navigate cooperation and competition in nascent ecosystems. Strategic Management Journal, 39 (12), 3163-3192.

Harris, L.C. \& Daunt, K.L. (2011). Deviant customer behaviour: A study of techniques of neutralisation. Journal of Marketing Management, 27 (7/8), 834-853.

Harris, L.C. \& Ogbonna, E. (2006). Service sabotage: A study of antecedents and consequences. Journal of the Academy of Marketing Science, 34 (4), 543-558.

Harris, L.C. \& Reynolds, K.L. (2003). The consequences of dysfunctional customer behaviour. Journal of Service Research, 6 (2), 144-161.

Hayward, D. \& Lewis, N. (2008). Regional dynamics in the globalising wine industry: The case of Marlborough, New Zealand. The Geographical Journal, 174 (2), 124-137.

Hollebeek, L.D. \& Brodie, R.J. (2009). Wine service marketing, value co creation and involvement: Research issues. International Journal of Wine Business Research, 21 (4), 339-353.

Jarzabkowski, P., Balogun, J. \& Seidl, D. (2007). Strategizing: The challenges of a practice perspective. Human Relations, 60 (1), 5-27.

Jarzabkowski, P. \& Bednarek, R. (2018). Toward a social practice theory of relational competing. Strategic Management Journal, 39 (3), 794-829.

Johnson, G., Melin, L. \& Whittington, R. (2003). Micro strategy and strategizing: Towards an activity-based view. Journal of Management Studies, 40 (1), 3-22.

Katsikeas, C.S., Morgan, N.A., Leonidou, L.C. \& Hult, G.T.M. (2016). Assessing performance outcomes in marketing. Journal of Marketing, 80 (2), 1-20. 
Klaus, P. \& Edvardsson, B. (2014). The road back to relevance: How to put marketing (and marketing scholars) back on the top managements' agendas. Journal of Service Management, 25 (2), 166-170.

Kraft, K.L. (1991). The relative importance of social responsibility in determining organizational effectiveness: Managers from two service industries. Journal of Business Ethics, 10 (7), 485-491. Kraft cites Newstrom, J.W. \& Ruch, W.A. (1975). The ethics of management and the management of ethics. MSU Business Topics, 23 (Winter), 2937.

Lado, A.A., Boyd, N.G., Wright, P. \& Kroll, M. (2006). Paradox and theorizing within the resource-based view. Academy of Management Review, 31 (1), 115-131.

Letaifa, S.B. \& Rabeau, Y. (2014). Too close to collaborate? How geographic proximity could impede entrepreneurship and innovation. Journal of Business Research, 66 (10), 2071-2078.

Le Roy, F.L. \& Sanou, F.H. (2014). Does coopetition strategy improve market performance? An empirical study in mobile phone industry. Journal of Economics and Management, 17 (1), 63-94.

Mathias, B.D., Huyghe, A., Frid, C.J. \& Galloway, T.L. (2018). An identity perspective on coopetition in the craft beer industry. Strategic Management Journal, 39 (12), 30863115.

Morrow, S.L. (2005). Quality and trustworthiness in qualitative research in counseling psychology. Journal of Counseling Psychology, 52 (2), 250-260.

New Zealand Winegrowers (2018). Available on the New Zealand Winegrowers website at: https://www.nzwine.com (accessed on various dates). 
Nicholson, J., Gimmon, E. \& Felzensztein, C. (2017). Economic geography and business networks: Creating a dialogue between disciplines. Industrial Marketing Management, 61 (Feb), 4-9.

O'Cass, A. \& Ngo, L.V. (2011). Examining the firm's value creation process: A managerial perspective of the firm's value offering strategy and performance. British Journal of Management, 22 (4), 646-671.

Park, B.J.R., Srivastava, M.K. \& Gnyawali, D.R. (2014). Walking the tight rope of coopetition: Impact of competition and cooperation intensities and balance on firm innovation performance. Industrial Marketing Management, 43 (2), 210-221.

Payne, A.F., Storbacka, K. \& Frow, P. (2008). Managing the co-creation of value. Journal of the Academy of Marketing Science, 36 (1), 83-96.

Piekkari, R., Plakoyiannaki, E. \& Welch, C. (2010). Good case research in industrial marketing: Insights from research practice. Industrial Marketing Management, 39 (1), 109-117.

Priem, R.L. \& Butler, J.E. (2001). Is the resource-based view a useful perspective for strategic management research? Academy of Management Review, 26 (1), 57-66.

Raza-Ullah, T., Bengtsson, M. \& Kock, S. (2014). The coopetition paradox and tension in coopetition at multiple levels. Industrial Marketing Management, 43 (2), 189-198.

Reynolds, K.L. \& Harris, L.C. (2009). Dysfunctional customer behavior severity: An empirical examination. Journal of Retailing, 85 (3), 321-335.

Ritala, P. (2012). Coopetition strategy - When is it successful? Empirical evidence on innovation and market performance. British Journal of Management, 23 (3), 307-324.

Ritala, P. \& Hurmelinna-Laukkanen, P. (2009). What's in it for me? Creating and appropriating value in innovation-related coopetition. Technovation, 29 (12), 819-828. 
Rusko, R. (2011). Exploring the concept of coopetition: A typology for the strategic moves of the Finnish forest industry. Industrial Marketing Management, 40 (2), 311-320.

Ryan, P., Evers, N., Smith, A. \& Andersson, S. (2019). Local horizontal network membership for accelerated global market reach. International Marketing Review, 36 (1): 6-30.

Sekhon, H., Ennew, C., Kharouf, H. \& Devlin, J. (2014). Trustworthiness and trust: Influences and implications. Journal of Marketing Management, 30 (3-4), 409-430.

Sinkovics, R.R. \& Alfoldi, E.A. (2012). Progressive focusing and trustworthiness in qualitative research: The enabling role of computer-assisted qualitative data analysis software (CAQDAS). Management International Review, 52 (6), 817-845.

Stake, R.E. (1995). The Art of Case Study Research. Thousand Oaks: Sage Publications.

Tadajewski, M. (2010). Critical marketing studies: Logical empiricism, 'critical performativity' and marketing practice. Marketing Theory, 10 (2), 210-222.

Taplin, I.M. (2006). Competitive pressures and strategic repositioning in the Californian premium wine industry. International Journal of Wine Marketing, 18 (1), 61-70.

Taplin, I.M. (2012). Innovation and market growth in a 'new world' wine region: The case of North Carolina. Journal of Wine Research, 23 (3), 229-246.

Thorpe, M. (2009). The globalisation of the wine industry: New world, old world and China. China Agricultural Economic Review, 1 (3), 301-313.

Tidstrom, A. (2014). Managing tensions in coopetition. Industrial Marketing Management, 43 (2), 261-271.

Verhoef, P.C. \& Leeflang, P.S.H. (2009). Understanding the marketing department's influence within the firm. Journal of Marketing, 73 (2), 14-37.

Virtanen, H. \& Kock, S. (2016). Tension in coopetition between small and medium-sized firms. McGill International Entrepreneurship Conference, Vaasa, Finland. 
Voronov, M., de Clercq, D. \& Hinings, C.R. (2013). Conformity and distinctiveness in a global institutional framework: The legitimation of Ontario fine wine. Journal of Management Studies, 50 (4), 607-645.

Whittington, R. (1996). Strategy as practice. Long Range Planning, 29 (5), 731-735.

Whittington, R. (2006). Completing the practice turn in strategy research. Organization Studies, 27 (5), 613-634.

Yu, T., Neuhofer, B. \& Viglia, G. (2018). When co-creation pays: Stimulating engagement to increase revenues. International Journal of Contemporary Hospitality Management, 30 (4), 2093-2111.

Yu, Y. \& Lindsay, V. (2016). Export commitment and the global financial crisis: Perspectives from the New Zealand wine industry. Journal of Small Business Management, 54 (2), 771-797. 
Table 1. Selected Characteristics of the Sampled Firms

\begin{tabular}{|l|l|l|l|l|l|}
\hline Firm & $\begin{array}{c}\text { *Staff } \\
\text { Members }\end{array}$ & $\begin{array}{c}\text { Export } \\
\text { Ratio } \\
(\%)\end{array}$ & $\begin{array}{c}\text { Wine } \\
\text { Tourism } \\
\text { Non- } \\
\text { Cellar } \\
\text { Door }\end{array}$ & $\begin{array}{l}\text { Main } \\
\text { Price } \\
\text { Point }\end{array}$ & $\begin{array}{c}\text { Perceived Source of } \\
\text { Competitive } \\
\text { Advantage }\end{array}$ \\
\hline 1 & 12 & 70 & $\checkmark$ & Low & Location \\
\hline 2 & 1 & 0.5 & & High & Boutique \\
\hline 3 & 22 & 80 & $\checkmark$ & Low & Augmentation \\
\hline 4 & 22 & 92 & $\checkmark$ & Low & Quality \\
\hline 5 & 3 & 5 & & High & Augmentation \\
\hline 6 & 7 & 35 & & High & Service \\
\hline 7 & 8 & 50 & $\checkmark$ & High & Heritage \\
\hline 8 & 4 & 60 & $\checkmark$ & High & Specialisation \\
\hline 9 & 60 & 30 & $\checkmark$ & High & Location \\
\hline 10 & 50 & 22 & $\checkmark$ & Low & Networks \\
\hline 11 & 10 & 50 & $\checkmark$ & High & Networks \\
\hline 12 & 2 & 8 & $\checkmark$ & Low & Experience \\
\hline 13 & 2 & 80 & & High & Service \\
\hline 14 & 35 & 30 & $\checkmark$ & Low & Experience \\
\hline 15 & 30 & 0.5 & & High & Quality \\
\hline 16 & 4 & 30 & & Low & Presentation \\
\hline 17 & 8 & 15 & $\checkmark$ & Low & Augmentation \\
\hline 18 & 2 & 0 & & Low & Boutique \\
\hline 19 & 24 & 70 & $\checkmark$ & High & Augmentation \\
\hline 20 & 2 & 0.5 & & Low & Experience \\
\hline 21 & 50 & 5 & $\checkmark$ & Low & Service \\
\hline 22 & 2 & 85 & & High & Heritage \\
\hline 23 & 2 & 90 & $\checkmark$ & Low & Location \\
\hline 24 & 24 & 50 & & Low & Heritage \\
\hline 25 & 35 & 40 & $\checkmark$ & High & Environmentalism \\
\hline & & & & & \\
\hline
\end{tabular}

*The number of staff members varied to a maximum at harvesting time. 
Table 2. Firms Placed in the Product Portfolio-Coopetition Matrix

\begin{tabular}{|c|c|c|c|c|}
\hline \multicolumn{4}{|c|}{ PRODUCT PORTFOLIO } & \\
\hline Narrow & \multicolumn{4}{|c|}{ Augmented } \\
\hline Community Service & $N=5$ & Team Player & $\mathbf{N}=\mathbf{1 0}$ & COOPETITION \\
\hline Firm 6 & & Firm 1 & & \\
\hline Firm 15 & & Firm 3 & & \\
\hline Firm 16 & & Firm 7 & & High \\
\hline Firm 20 & & Firm 9 & & \\
\hline Firm 24 & & Firm 10 & & \\
\hline Product Focus & $N=5$ & Service Focus & $N=5$ & \\
\hline Firm 2 & & Firm 4 & & \\
\hline Firm 5 & & Firm 8 & & \\
\hline Firm 13 & & Firm 11 & & Low \\
\hline Firm 18 & & Firm 17 & & \\
\hline Firm 22 & & Firm 23 & & \\
\hline
\end{tabular}

